The Future of the Self 
The publisher and the University of California Press Foundation gratefully acknowledge the generous support of the Simpson Imprint in Humanities. 


\section{The Future of the Self}

An Interdisciplinary Approach to Personhood

and Identity in the Digital Age

JAY FRIEDENBERG

甲

UNIVERSITY OF CALIFORNIA PRESS 
University of California Press

Oakland, California

(C) 2020 by Jay Friedenberg

Library of Congress Cataloging-in-Publication Data

Names: Friedenberg, Jay, author.

Title: The future of the self : an interdisciplinary approach to personhood and identity in the digital age / Jay Friedenberg.

Description: Oakland, California : University of California Press, [2020] | Includes bibliographical references and index.

Identifiers: LCCN 20I9048352 (print) | LCCN 20I9048353 (ebook) | ISBN 9780520302426 (cloth) | ISBN 9780520298484 (paperback) | ISBN 9780520970595 (ebook)

Subjects: LCSH: Self-presentation. | Identity (Psychology) | Brain. | Information technologySocial aspects. | Online identities. | Avatars (Virtual reality)

Classification: LCC BF697.5.S44 F75 2020 (print) | LCC BF697.5.S44 (ebook) | DDC 155.2-dc23

LC record available at https://lccn.loc.gov/2019048352

LC ebook record available at https://lccn.loc.gov/20I9048353

Manufactured in the United States of America

$\begin{array}{llllllllll}29 & 28 & 27 & 26 & 25 & 24 & 23 & 22 & 21 & 20\end{array}$

I0 $9 \begin{array}{lllllllll} & 8 & 7 & 6 & 5 & 4 & 3 & 2 & \text { I }\end{array}$ 